\title{
Lectotypification of Papaver cambricum L. (Papaveraceae)
}

\section{P. Pablo Ferrer-Gallego}

\begin{abstract}
FERRER-GALLEGO, P. P. (2015). Lectotypification of Papaver cambricum L. (Papaveraceae). Candollea 70: 207-210. In English, English abstract. DOI: http://dx.doi.org/10.15553/c2015v702a5

The typification of the name Papaver cambricum L. (Papaveraceae) is discussed. This species was previously accepted in the genus Meconopsis Vig. as Meconopsis cambrica (L.) Vig. The protologue of the name and the original material are evaluated. A specimen from the Burser Herbarium (UPS-BURSER) is designated as the lectotype.
\end{abstract}

\section{Keywords}

PAPAVERACEAE - Meconopsis - Papaver - Lectotypification 


\section{Introduction}

The genus Meconopsis Vig. (Papaveraceae) comprises approximately 70 perennial monocarpic or polycarpic herbs, distributed primarily in southern central Asia (GREY-WILSON, 2014). The western European M. cambrica (L.) Vig. was long considered to be the only European representative of the genus. However, new molecular studies suggest that it does not belong to the Asian species of Meconopsis but should rather be accepted in Papaver L. (Kadereit et al., 1997, 2011; Carolan et al., 2006). As Meconopsis cambrica was the original type of Meconopsis, the genus would have been considered as a synonym of Papaver and therefore left the Asian species without a generic name. GREY-WILSON (2012) further proposed the name Meconopsis for conservation with a proposed conserved type: $M$. regia G. Taylor. This proposal was strongly recommended by the Nomenclature Committee for Vascular Plants (APPLEQUist, 2013).

Meanwhile, Grey-Wilson (2014) placed Papaver cambricum L. in the monotypical genus Parameconopsis Grey-Wilson.

However, the name Papaver cambricum L. has not yet been typified (JARvis, 2007: 722). This paper proposes the designation of a lectotype for this name based on the protologue and consultation of Linnaeus's original material.

\section{Typification}

The protologue of $P$. cambricum (Linnaeus, 1753: 508) presents four synonyms. The first synonym is cited from Linnaeus (1738: 201) and Royen (1740: 479) "Papaver foliis pinnatis, fructu acuminato", the second from DilleNIUS (1732: 300, t. 223, f. 290) "Papaver cambricum perenne, flore sulphureo", the third from Morison (1680: 279, s. 3, t. 14, f. 12) "Argemone cambro-britannica lutea, capite longiore glabro", and the fourth from Baunin (1620: 92, 1623: 171) "Papaver erraticum pyrenaicum, flore flavo". "Burs. IX: 45 " is the citation of a specimen in UPS-BURSER (Herb. Burser IX: 45), which is therefore a syntype. Two of the synonyms are accompanied by illustrations (Morison, 1680; Dillenius, 1732), which are also original material.

Linnaeus's original material additionally includes two uncited specimens (JARvis, 2007: 723). At LINN, the specimen "Herb. Linn. No. 669.9" bears the annotation "7 cambricum" by Linnaeus, explicitly referring to the number of the species account of $P$. cambricum in Linnaeus (1753: 508) (see Stearn, 1957; Turland \& Jarvis, 1997; Turland, 2006; JARVIs, 2007: 41-46, 397). The specimen is a stem with leaves, a flower and a flower bud, but no fruit.

The sheet preserved in the Clifford Herbarium, "Herb. Clifford: 201", Papaver 4 (BM000628706) is annotated "Papaver erraticum pyrenaicum flore flavo C.B.P. 171 / Papaver foliis pinnatis, fructu acuminato H. Cl. IV. p. 201". The specimen is a stem with leaves and three flowers, but no fruit.

Finally, the syntype in UPS-BURSER bears two fragments, one with a flower, the other with a flower bud, and a label with the annotation "Papaver erraticum pyrenaicum flore flavo Bauh. / In Pyrenaeis" (see Savage, 1937: 27). No further original material have been found in any of the other Linnaean and Linnaean-linked herbaria.

The specimen in UPS-BURSER has precedence in lectotype designation over the uncited specimens and cited illustrations. It is therefore the obligate lectotype and must be designated as such. Fortunately it is in a good state of preservation, and it conforms with the other Linnean specimens and illustrations and with the traditional and current use of the names P. cambricum and Meconopsis cambrica.

Papaver cambricum L., Sp. P1.: 508. 1753.

$\equiv$ Meconopsis cambrica (L.) Vig., Hist. Nat. Pavots: 48. 1814.

$\equiv$ Parameconopsis cambrica (L.) Grey-Wilson, Meconopsis: 367.2014.

Lectotypus (here designated): Herb. Burser IX: 45 (UPSBURSER!) (Fig. 1).

\section{Acknowledgements}

The author thanks Dr. Mats Hjertson (Museum of Evolution, Botany Section Uppsala University, Sweden) for his help as well as an anonymous reviewer.

\section{References}

Applequist, W. L. (2013). Report of the Nomenclature Committee for Vascular Plants: 65. Taxon 62: 1315-1326.

Bauhin, C. (1620). Prodromus theatri botanici. Francofurti ad Moenum.

Bauhin, C. (1623). Pinax theatri botanici. Basileae.

Carolan, J. C., I. L. I. Нook, M. W. Chase, J. W. Kadereit \& T. R. Hodkinson (2006). Phylogenetics of Papaver and related genera based on DNA sequences from ITS nuclear ribosomal DNA and plastid trnL intron and trnL-F intergenic spacers. Ann. Bot. (Oxford) 98: 141-155.

Dillenius, J. J. (1732). Hortus Elthamensis. Londini.

Grey-Wilson, C. (2012). (2061) Proposal to conserve the name Meconopsis (Papaveraceae) with a conserved type. Taxon 61: 473-474.

Grey-Wilson, C. (2014). The genus Meconopsis: Blue poppies and their relatives. Royal Botanic Gardens, Kew.

JARvis, C. (2007). Order out of chaos: Linnaean plant names and their types. Linnean Society of London \& Natural History Museum, London.

Kadereit, J. W., C. D. Preston \& J. F. Valtueña (2011). Is Welsh Poppy, Meconopsis cambrica (L.) Vig. (Papaveraceae), truly a Meconopsis? New J. Bot. 1: 80-87. 


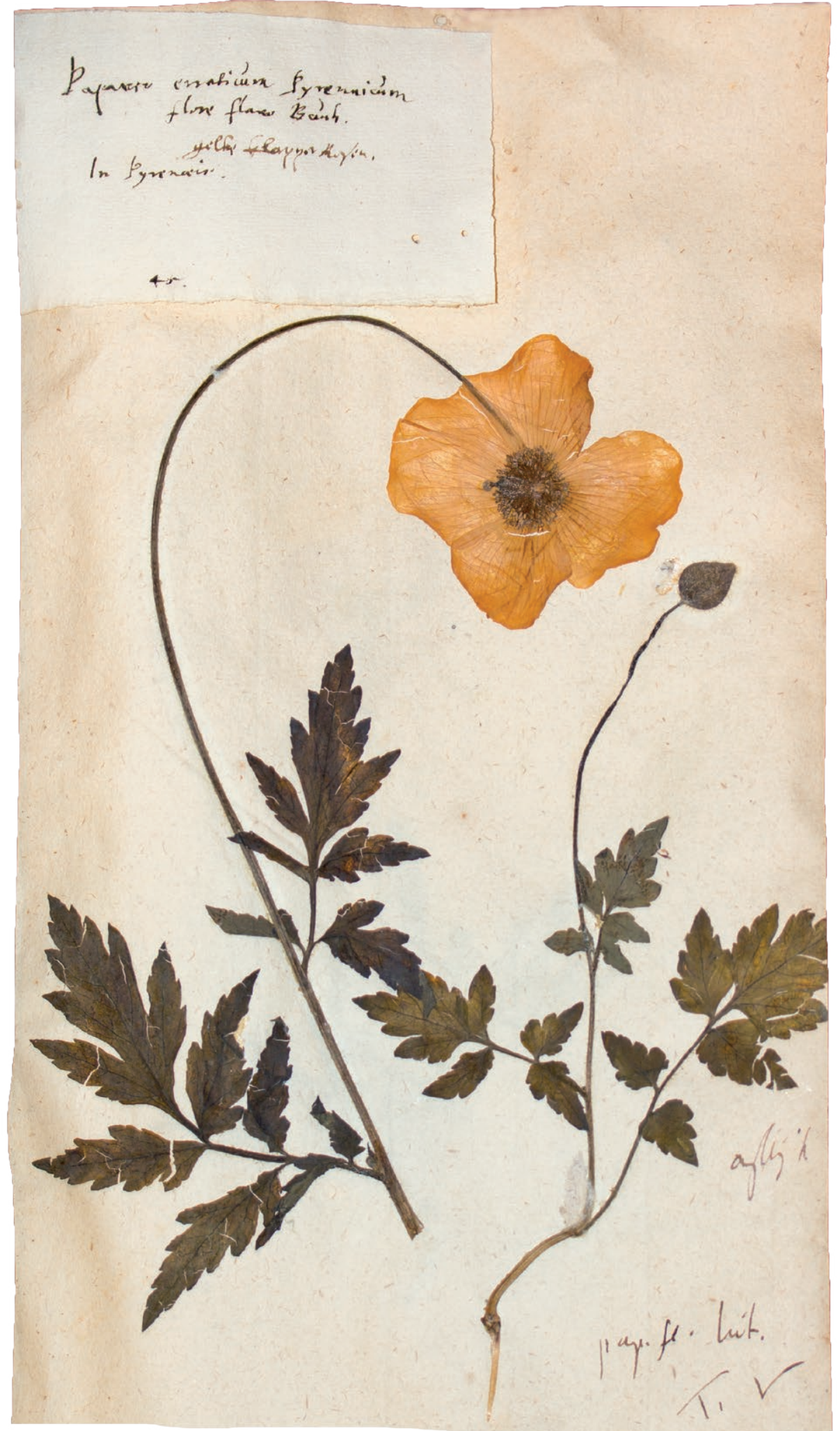

Fig. 1. - Lectotype of Papaver cambricum L.

[Herb. Burser IX: 45, UPS-BURSER] [๑ Herbarium UPS. Reproduced with permission] 
Kadereit, J. W., A. E. Schwarzbach \& K. B. Jork (1997). The phylogeny of Papaver s.l. (Papaveraceae): polyphyly or monophyly? Pl. Syst. Evol. 204: 75-98.

Linnaeus, C. (1738). Hortus Cliffortianus. Amsterdam.

Linnaeus, C. (1753). Species Plantarum. Holmiae.

Morison, R. (1680). Plantarum historiae universalis Oxoniensis pars secunda. Oxford.

Royen, A. van (1740). Florae Leydensis prodromus, exhibens plantas quae in horto academico Lugduno-Batavo aluntur. Lugduni Batavorum.

Savage, S. (1937). Caroli Linnaei determinationes in Hortum Siccum Joachimi Burseri. The text of the manuscript in the Linnaean Collections. Linnean Society, London.

Stearn, W. T. (1957). An introduction to the Species Plantarum and cognate botanical works of Carl Linnaeus. In: Linnaeus, C., Species Plantarum, a facsimile of the first edition, 1753. Vol. 1. Ray Society, London.

Turland, N. J. (2006). Lectotypification of Campanula saxatilis, Phyteuma pinnatum and Verbascum arcturus, Linnaean names of three taxa endemic to Crete. Willdenowia 36: 303-309.

Turland, N. J. \& C. E. Jarvis (1997). Typification of Linnaean specific and varietal names in the Leguminosae (Fabaceae). Taxon 46: 457-485. 